\title{
METODE BUZZ GROUP DISERTAI MEDIA KELERENG SEBAGAI UPAYA MENINGKATKAN HASIL BELAJAR MATEMATIKA SISWA KELAS I SD NEGERI 023898 BINJAI UTARA
}

\author{
Sufriati \\ Guru SD Negeri 023898 Binjai Utara \\ Sufriati679@yahoo.com
}

\begin{abstract}
This study aims to find out how to improve the results of mathematics learning on the subject of summing in integers through Buzz Group method along with media Kelereng on the students of class I SD Negeri 020580 Binjai. And how the creativity and ability of teachers in implementing learning in the classroom. The result of this research concludes that the result of student learning in learning through Buzz Group method is On cycle I the good categorization value reaches only 20\%. That means that a small part of the first cycle is more increased than before the improvement of learning. Nevertheless, the less categorized students are still in the most process that is $40 \%$ and the categorized is as much as $40 \%$ that finally in the second cycle the number of students who are categorized moderate and less should decrease. In cycle II, good categorized value is much more and melngalami significant achievement increase that reaches $80 \%$. then the students who get the category is $20 \%$. After the main problems in the improvement of learning on the cycle I and II implemented, the authors were satisfied with the increase in student value on the implementation of improvement learning in cycle II seen in the moderate category decreased and the absence of students who got less value
\end{abstract}

Keywords: buzz group, integers, marbels media

\begin{abstract}
Abstrak. Penelitian ini bertujuan untuk mengetahui bagaimana meningkatkan hasil belajar matematika pada pokok materi Penjumlahan pada bilangan Bulat melalui metode buzz group disertai media Kelereng pada siswa kelas I SD Negeri 020580 Binjai. Serta bagaimana kreatifitas dan kemampuan guru dalam melaksanakan pembelajaran di dalam kelas. Hasil penelitian menyimpulkan bahwa hasil belajar siswa dalam pembelajaran melalui metode buzz group adalah Pada siklus I nilai yang berkategori baik baru mencapai $20 \%$. Itu artinya sebagian kecil pada siklus kesatu lebih meningkat dari pada sebelum adanya perbaikan pembelajaran. Meskipun demikian, siswa yang berkategori kurang masih dalam proses terbanyak yaitu sebesar $40 \%$ dan yang berkategori sedang sebanyak $40 \%$ itu akhirnya pada siklus kedua jumlah siswa yang berkategori sedang dan kurang harus mengalami penurunan. Pada Siklus II, Nilai yang berkategori baik jauh lebih banyak dan melngalami kenaikan prestasi yang cukup signifikan yaitu mencapai $80 \%$. Selanjutnya siswa yang mendapatkan kategori sedang terdapat $20 \%$. Setelah permasalahan utama pada perbaikan pembelajaran pada siklus I dan II dilaksanakan, penulis merasa puas dengan meningkatnya nilai siswa pada pelaksanaan perbaikan pembelajaran pada siklus II dilihat pada kategori sedang yang mengalami penurunan serta tidak terdapatnya siswa yang mendapat nilai kurang.
\end{abstract}

Kata Kunci: buzz group, bilangan bulat, media kelereng

\section{PENDAHULUAN}

Pendidikan merupakan suatu cara pembentukan kemampuan manusia untuk menggunakan akal pikiran/rasional mereka sebagai jawaban dalam menghadapi berbagai masalah yang timbul di masa yang akan datang. Pendidikan juga merupakan usaha sadar yang sengaja dirancang untuk mencapai tujuan yang telah ditetapkan. Salah satu tujuan pendidikan yaitu untuk meningkatkan kualitas sumber daya manusia. Melalui pendidikan yang baik, kita akan mudah mengikuti perkembangan zaman di 
masa yang akan datang, khususnya perkembangan dalam bidang ilmu pengetahuan dan teknologi (IPTEK).

Usaha yang dilakukan pemerintah dalam meningkatkan mutu pendidikan di Indonesia, khususnya pendidikan matematika di sekolah sudah banyak dilakukan, salah satunya dengan perubahan kurikulum serta melalui kelengkapan sarana dan prasarana pendidikan. Namun, sampai saat ini mutu pendidikan di Indonesia masih belum mendapat hasil yang memuaskan, baik ditinjau dari proses pembelajarannya maupun hasil belajar siswanya. Menurut Gagne, belajar didefinisikan sebagai suatu proses dimana suatu organisme berubah perilakunya akibat suatu pengalaman (Setyawan, 2009:1). Pembelajaran adalah proses yang diselenggarakan oleh guru untuk membelajarkan siswa dalam belajar, bagaimana belajar memperoleh dan memproses pengetahuan, keterampilan, dan sikap (Dimyati dan Mudjiono, 2002:157).

Matematika merupakan ilmu yang mendasari perkembangan teknologi modern. Selain itu, matematika merupakan sarana berfikir dalam menentukan sekaligus mengembangkan ilmu pengetahuan dan teknologi, mempunyai peran penting dalam berbagai macam disiplin, dan dapat memajukan daya fikir manusia. Untuk menciptakan dan menguasai teknologi di masa depan, diperlukan penguasaan matematika yang kuat sedini mungkin. Mata pelajaran matematika diberikan kepada semua peserta didik mulai dari sekolah dasar untuk membekali peserta didik dengan kemampuan berfikir logis, analistis, sistematis, kritis, kreatif dan kemampuan bekerjasama (Depdiknas 2006:93). Namun demikian matematika dianggap sebagai pelajaran yang sangat sulit dipahami karena selalu berkaitan dengan angka dan rumus. Hal tersebut menjadi penyebab rendahnya hasil belajar matematika. Pernyataan tersebut didukung dari kenyataan yang ada di lapangan yang menunjukkan bahwa hasil belajar matematika 020580 Binjai Utara tergolong rendah dibandingkan dengan mata pelajaran yang lainnya.

Berdasarkan hasil observasi, rendahnya nilai hasil belajar siswa di SD Negeri 020580 Binjai Utara disebabkan oloeh beberapa faktor antara lain metode pembelajaran yang diterapkan di sekolah masih bersifat konvensional dan penggunaan alat peraga/media jarang sekali digunakan, sehingga pemahaman terhadap konsep matematika sulit dicerna. siswa kurang dilibatkan dalam proses pembelajaran dan cenderung pasif, terbukti dalam kegiatan belajar siswa selalu diam saja ketika mendapat kesulitan dalam belajar, siswa selalu menunggu guru untuk diberikan contoh-contoh soal dan cara pengerjaannya yang benar tanpa mencoba berfikir untuk menggali dan membangun idenya sendiri, siswa tidak pernah mengajukan pertanyaan yang dianggap kurang mengerti dan siswa tidak berani menjawab pertanyaan serta mempresentasikan jawaban di depan kelas. Karena metode ini lebih baik jika diubah dengan metode yang melibatkan siswa secara aktif dalam proses belajar mengajar yang produktif.

Menurut informasi yang diberikan oleh guru di SD Negeri 020580 Binjai Utara khususnya kelas I mendapat permasalahan yang dihadapi oleh siswa yaitu kurangnya kemampuan siswa dalam memecahkan masalah ketika pada penjumlahan bilangan bulat. Terlihat dalam mengerjakan soal, siswa tidak mengerti apa yang harus dilakukan untuk menghitung penjumlahan dengan cara yang lebih mudah, tidak bisa merencanakan bagaimana cara menyelesaikan (menemukan pola atau rumus matematika), menyelesaikan rencana (mengerjakan jawaban), dan memeriksa kembali jawaban yang telah diperoleh. Pernyataan tersebut didukung pula pada hasil nilai ulangan harian siswa pada Penjumlahan pada bilangan bulat yaitu dari 25 siswa, hanya 
5 siswa tuntas belajar (sesuai SKM yaitu $\geq 60$ ), sedangkan 20 siswa tidak tuntas belajar. Jadi persentase ketuntasan belajar siswa di kelas I yaitu siswa yang tuntas belajar sekitar $20 \%$ dan yang tidak tuntas belajar sekitar $80 \%$.

Paradigma pembelajaran saat ini telah berkembang dari pembelajaran yang berpusat pada guru ke pembelajran yang berpusat kepada siswa, termasuk pembelajaran matematika.pelaksanaan pembelajaran harus dilaksanakan dengan sebuah pendekatan yang tepat. Untuk mendukung proses pembelajaran yang sesuai dengan perubahan paradigm baru tersebut, dibutuhkan pengembangan pembelajaran dengan sebuah pendekatan yang berfokus pada kegiatan siswa. Metode sebagai salah satu komponen pembelajaran, menempati peran yang tidak kalah pentingnya dari komponen lainnya dalam kegiatan belajar mengajar.Tidak ada satupun kegiatan belajar mengajar yang tidak menggunakan metode pembelajaran. Ini berarti guru memahami benar kedudukan metode sebagai alat motifasi ekstrinsik dalam kegiatan belajar mengajar. Motivasi ekstrinsik menurut Sardiman, (2014) adalah motif-motif yang aktif dan berfungsi, karena adanya rangsang dari luar. Karena itu, metode berfungsi sebagai alat perangsang dari luar yang dapat membangkitkan motifasi belajar seseorang (Djamarah dan Zain, 2006).

Penggunaan metode buzz group merupakan salah satu alternatif untuk membantu siswa menyelesaikan soal matematika yang berkaitan dengan penjumlahan bilangan bulat. Alasan pemilihan pembelajaran menggunakan metode buzz group dengan media gambar dimaksudkan untuk membandingkan interpretasi dan informasi pengetahuan yang diperoleh masing-masing siswa, agar dapat saling aktif dalam memperbaiki pengertian, persepsi, informasi, dan interprestasi, sehingga dapat menghindarkan kekeliruan dan miskonsepsi dalam menerima materi pelajaran. Sedangkan guru lebih berperan sebagai organisator, sehingga dalam pembelajaran ini memungkinkan para siswa semakin aktif dan interaktif.

Dalam proses belajar mengajar kehadiran media mempunyai arti yang sangat penting karena media dapat membangkitkan keinginan dan minat yang baru, membangkitkan motivasi dan rangsangan kegiatan belajar dan bahkan membawa pengaruh-pengaruh psikologi terhadap siswa. Oleh karena itu diperlukan media atau alat peraga agar siswa dapat menguasai konsep penjumlahan pada bilangan bulat, media dalam proses belajar mengajar cenderung diartikan sebagai alat-alat grafis, photografis, atau elektronis untuk menangkap, memproses, dan menyusun kembali informasi visual atau verbal (Arsyad, 2006:3). Media kelereng merupakan media sederhana yang mudah di dapat, mudah dibawa dan tersedia di sekitar siswa. Dengan menggunakan media kelereng siswa akan lebih mudah memahami konsep penjumlahan pada bilangan bulat. Siagian (2016:65) menjelaskan bahwa suatu pemahaman diperoleh oleh siswa melalui suatu rangkaian proses yang dilalui oleh siswa saat belajar dan interaksi yang terjadi saat belajar bersama orang lain, sehingga siswa dapat membentuk pengetahuan dan pemahaman dari apa yang dialaminya.

\section{METODE}

Subjek dari penelitian ini adalah siswa Kelas I Semester genap SD Negeri 020580 Binjai Utara tahun pelajaran 2016/2017. Objek dari penelitian adalah hasil belajar penjumlahan bilang bulat siswa kelas I SD Negeri 020580 Binjai Utara melaui metode buzz group disertai media kelereng. Penelitian ini menggunakan desain penelitian tindakan kelas yang terdiri dari 2 siklus. Setiap siklus terdiri dari beberapa 
tahapan yaitu tahap perencanaan, tindakan, observasi dan refleksi. Jika pada siklus I sudah mencapai ketuntasan hasil belajar maka siklus II tidak perlu dilakukan.

Dalam rangka menyusun dan mengolah data yang terkumpul sehingga dapat menghasilkan suatu kesimpulan yang dapat dipertanggungjawabkan, maka digunakan analisis data kuantitatif dan pada metode observasi digunakan data kualitatif. Cara perhitungan untuk mengetahui ketuntasan belajar siswa dalam proses belajar mengajar sebagai berikut:

1. Merekapitulasi hasil tes.

2. Merekapitulasi hasil pengamatan.

3. Menghitung jumlah skor yang tercapai dan prosentasenya untuk masing-masing siswa dengan menggunakan rumus ketuntasan belajar seperti yang terdapat dalam buku petunjuk teknis penilaian yaitu siswa dikatakan tuntas secara individual jika mendapatkan nilai minimal 60, sedangkan secara klasikal dikatakan tuntas belajar jika jumlah siswa yang tuntas secara individu mencapai $80 \%$ yang telah mencapai daya serap lebih dari sama dengan 60 .

\section{HASIL DAN PEMBAHASAN HASIL}

Berdasarkan hasil penelitian yang dilakukan di kelas I SD Negeri 020580 Binjai Utara, maka diperoleh data yang menunjukkan aktifitas siswa dalam proses pembelajaran. Selain dari itu terdapat beberapa hasil pembelajaran yang diperoleh setelah penulis melakukan penelitian. Adapun hasil dari penelitian mata pelajaran matematika di kelas I SD Negeri 020580 Binjai Utara. Dapat dilihat pada tabel berikut:

Tabel 1. Analisis Kategori Evaluasi Siklus I

\begin{tabular}{ccc}
\hline Kategori & Jumlah Siswa & Persentase (\%) \\
\hline Baik & 5 Orang & $20 \%$ \\
\hline Sedang & 10 Orang & $40 \%$ \\
\hline Kurang & 10 Orang & $40 \%$ \\
\hline
\end{tabular}

Tampak pada analisis kategori diatas bahwa nilai yang berkategori baik baru mencapai $20 \%$. Itu artinya sebagian kecil pada siklus kesatu lebih meningkat dari pada sebelum adanya perbaikan pembelajaran. Meskipun demikian, siswa yang berkategori kurang masih dalam proses terbanyak yaitu sebesar $40 \%$ dan yang berkategori sedang sebanyak $40 \%$ itu akhirnya pada siklus kedua jumlah siswa yang berkategori sedang dan kurang harus mengalami penurunan. Berdasarkan hasil diskusi dengan teman sejawat, pembelajaran yang sudah dilaksanakan sudah ada kemajuan. Adapun temuan dan refleksi dari hasil penelitian diperoleh sebanyak 2 orang siswa memperoleh nilai 8,2 orang siswa memperoleh nilai 7, 9 orang siswa memperoleh nilai 6 , dan 12 orang siswa memperoleh nilai 5. Dengan demikian bisa terlihat pada tahapan siklus I yang menunjukkan bahwa kenaikan hasil evaluasi siswa belum terlihat signifikan, tetapi apabila dibandingkan pada sebelum ada perbaikan masih dapat dikategorikan lebih baik dari sebelumnya karena pada siklus I tidak terdapat nilai dibawah 4 kebawah. Dengan demikian penulis mencoba pada tahapan selanjutnya yaitu di tahap siklus II.

Setelah permasalahan utama yang menjadi fokus perbaikan dalam mata pelajaran matematika, penulis mencoba memperbaiki terhadap proses pembelajaran serta meminta bantuan kepada teman sejawat untuk mengidentifikasi faktor penyebab rendahnya tingkat penguasaan terhadap materi pelajaran yang disampaikan. Dan 
akhirnya dari hasil refleksi dan diskusi dengan teman sejawat ditemukan beberapa penyebab, antara lain adalah sebagai berikut: 1) guru terlalu cepat dalam menyampaikan pembelajaran; 2) guru kurang menguasai dalam penggunaan alat peraga; 3) guru kurang menyampaikan tujuan pembelajaran; 4) guru kurang memberikan penguatan terhadap siswa; dan 5) tidak adanya diskusi antara siswa dan guru.

Tabel 2. Analisis Kategori Evaluasi Siklus II

\begin{tabular}{ccc}
\hline Kategori & Jumlah Siswa & Persentase (\%) \\
\hline Baik & 20 Orang & $80 \%$ \\
\hline Sedang & 5 Orang & $20 \%$ \\
\hline Kurang & - & - \\
\hline
\end{tabular}

Tampak pada analisis kategori diatas bahwa nilai yang berkategori baik jauh lebih banyak dan melngalami kenaikan prestasi yang cukup signifikan yaitu mencapai $80 \%$. Artinya pada siklus kedua sudah menunjukkan tingkat keberhasilan proses pembelajaran dengan hal ini maka cukup hanya sampai siklus II karena sampai tahap ini tingkat keberhasilan belajar sudah tercapai. Selanjutnya siswa yang mendapatkan kategori sedang terdapat $20 \%$. Hal ini jelas terlihat bahwa prestasi siswa sedang mengalami penurunan yang signifikan. Setelah permasalahan utama pada perbaikan pembelajaran pada siklus I dan II dilaksanakan, penulis merasa puas dengan meningkatnya nilai siswa pada pelaksanaan perbaikan pembelajaran pada siklus II dilihat pada kategori sedang yang mengalami penurunan serta tidak terdapatnya siswa yang mendapat nilai kurang.

Telah terjadi hasil peningkatan hasil belajar, hal ini terbukti dengan hasil evaluasi dengan rincian sebanyak 15 orang siswa memperoleh nilai sebesar 9,8 orang siswa memperoleh nilai sebesar 8,2 orang siswa memperoleh nilai sebesar 7. Dengan demikian terjadi perubahan yang sangat signifikan antara hasil dari penelitian siklus II, dimana pada siklus II terdapat hasil evaluasi yang dapat dikategorikan baik.dengan demikian penelitian sudah dapat dikatakan berhasil pada siklus II serta tidak ada tahapan siklus selanjutnya karena pada siklus II sudah dapat dikategorikan baik.

\section{Pembahasan}

Berdasarkan temuan data yang diperoleh dari proses perbaikan pembelajaran yang dilaksanakan terbukti menunjukkan ada perubahan belajar siswa yang signifikan dari perkembangan siswa yang dengan adanya upaya dan desain serta metode pembelajaran yang diupayakan pada setiap siklusnya. Hal ini terbukti dengan hasil yang tampak dari kemajuan yang dialami oleh masing-masing siswa yang semakin meningkat dilihat dari rekapitulasi nilai perbaikan pembelajaran. Pelaksanaan proses perbaikan yang telah dilaksanakan pada mata pembelajaran matematika tentang penggunaan penjumlahan cara susun untuk meningkatkan pemahaman siswa terhadap penjumlahan, dengan demikian penulis menggunakan metode cara susun dengan menggunakan media kelereng yang dijadikan alat bantu untuk proses penjumlahan bilangan dalam teknik penjumlahan cara susun. Pada tahapan pertama terdapat sedikit kenaikan hasil pembelajaran, hal ini didasarkan oleh penyampaian guru yang terlalu cepat dan kurang adanya sistem diskusi antara siswa dengan guru. Oleh sebab itu tahapan pertama yaitu pada siklus I hanya sedikit mengalami kenaikan serta belum begitu signifikan. Setelah melakukan berbagai diskusi dengan teman sejawat, maka 
penulis mencoba mendesain pola pembelajaran yang lebih kreatif yaitu disamping menggunakan media teknik cara susun dalam penyampaian materi penjumlahan dalam proses pembelajaran, penulis juga menggunakan sistem diskusi tanya jawab dengan mencoba uji keberanian terhadap siswa.

\section{KESIMPULAN DAN SARAN}

\section{Kesimpulan}

Dari hasil pengolahan dan analisis data, maka dari hasil perbaikan pembelajaran telah dilaksanakan dapat ditarik kesimpulan yaitu sebagai berikut:

1. Pada siklus I nilai yang berkategori baik baru mencapai $20 \%$. Itu artinya sebagian kecil pada siklus kesatu lebih meningkat dari pada sebelum adanya perbaikan pembelajaran. Meskipun demikian, siswa yang berkategori kurang masih dalam proses terbanyak yaitu sebesar $40 \%$ dan yang berkategori sedang sebanyak $40 \%$ itu akhirnya pada siklus kedua jumlah siswa yang berkategori sedang dan kurang harus mengalami penurunan.

2. Pada siklus II, nilai yang berkategori baik jauh lebih banyak dan melngalami kenaikan prestasi yang cukup signifikan yaitu mencapai $80 \%$. Selanjutnya siswa yang mendapatkan kategori sedang terdapat $20 \%$.

3. Setelah permasalahan utama pada perbaikan pembelajaran pada siklus I dan II dilaksanakan, penulis merasa puas dengan meningkatnya nilai siswa pada pelaksanaan perbaikan pembelajaran pada siklus II dilihat pada kategori sedang yang mengalami penurunan serta tidak terdapatnya siswa yang mendapat nilai kurang.

\section{Saran}

Dengan mengacu terhadap kesimpulan, maka dari itu penulis dapat memberikan saran yaitu sebagai berikut:

1. Dalam menyampaikan proses pembelajaran guru sebaiknya tidak terlalu cepat dalam menjelaskan materi pembelajaran.

2. Guru harus memberikan kesempatan kepada siswa untuk bertanya, dengan demikian siswa bisa lebih berani dan mampu untuk menerima materi yang disajikan.

\section{DAFTAR PUSTAKA}

Arsyad. 2006. Media Pembelajaran. Jakarta: Raja Grafindo Persada.

Depdiknas. 2006. Kurikulum Tingkat Satuan Pendidikan. Jakarta: Departemen Pendidikan Nasional.

Dimyati dan Mudjiono. 2002. Belajar dan Pembelajaran. Jakarta: Rineka Cipta. Djamarah dan Zain. 2006. Strategi Belajar Mengajar. Jakarta Rineka Cipta.

Sardiman, A. M. 1987. Interaksi dan Motivasi Belajar Mengajar. Jakarta: Rajawali Pers.

Setyawan. 2009. Pengertian Hasil Belajar.Yogyakarta: Hanindita GrahaWidya.

Siagian, M. D. 2016. Kemampuan Koneksi Matematik dalam Pembelajaran Matematika. MES (Journal of Mathematics Education and Science). 2(1). 5867. 